\title{
TRANSPORT AND CONSUMPTION OF ORGANIC DETRITUS IN A NEOTROPICAL LIMESTONE CAVE
}

\author{
PRENOS IN PORABA ORGANSKEGA DETRITA V NEOTROPSKI \\ KRAŠKI JAMI
}

\author{
Marconi SOUZA-SILVA ${ }^{1}$, Leopoldo FERREIRA DE OLIVEIRA BERNARDI ${ }^{2,4}$, Rogério PARENTONI MARTINS ${ }^{3}$ \\ \& Rodrigo LOPES FERREIRA ${ }^{4}$
}

\begin{abstract}
UDC 543.38:551.435.84

Marconi Souza Silva, Leopoldo Ferreira de Oliveira Bernardi, Rogério Parentoni Martins \& Rodrigo Lopes Ferreira: Transport and consumption of organic detritus in a neotropical limestone cave

Caves are permanently aphotic environments, a fact that precludes the occurrence of photosynthetic organisms. In these systems the resource is allochthonous, coming mainly from the surrounding epigean environment, being imported by physical and biological agents. Even knowing about the importance of the organic allochthonous resources in caves, little is known of their importation and processing. The present work had as an objective, the measuring the coarse particulate organic matter processing and import rates in the subterranean environment. The cave studied was Lapa da Fazenda Extrema I, limestone cave, located in Brazilian savanna biome. Through bimonthly collections, it was observed that the organic detritus penetrated into the cave in low amounts in dry season and high amounts in rainy season. The processing of the organic plant matter in the aquatic hypogean environment was moderate $\left(\mathrm{K}^{\text {-day }}=0.025\right)$, in the epigean environment the processing was predominantly slow $\left(\mathrm{K}^{\text {-day }}=0.0104\right)$. The detritus commonly brought to the interior of the cave were large woods ( $58.18 \mathrm{~g} /$ day), followed by leaves and fragmented material $(12.76 \mathrm{~g} /$ day $)$, fruits and seeds $(0.0069 \mathrm{~g} /$ day $)$, animal carcasses $(0.002 \mathrm{~g} /$ day $)$ and roots $(0.001 \mathrm{~g} /$ day $)$. The highest richness and abundances of invertebrates were found in the same periods in which there were the highest rates of organic matter import to the cave.
\end{abstract}

Keywords: cave, detritus processing, energy flow.

\author{
Izvleček UDK 543.38:551.435.84 \\ Marconi Souza Silva, Leopoldo Ferreira de Oliveira Bernardi, \\ Rogério Parentoni Martins \& Rodrigo Lopes Ferreira: Prenos \\ in poraba organskega detrita v neotropski kraški jami
}

Jame so stalno afotično okolje, ki onemogoča prisotnost fotosintetskih organizmov. Vsi osnovni viri so alohtoni in večinoma izvirajo z bližnjih površinskih sistemov. Pomen organskih alohtonih virov v podzemlju je dobro poznan, manj pa vemo o hitrosti njihovega vnosa $\mathrm{v}$ jame in procesih njihove pretvorbe. Delo obravnava hitrost vnosa in pretvorbe organskih delcev na primeru jame Lapa da Fazenda Extrema I v Brazilski savani. $\mathrm{Z}$ dvomesečno frekvenco vzorčenja smo ugotovili, da največ organskih delcev $\mathrm{v}$ jamo pride $\mathrm{v}$ deževni dobi, veliko manj $\mathrm{v}$ sušni. Pretvorba rastlinskih delcev v vodnem jamskem okolju je zmerna $\left(\mathrm{K}^{-\mathrm{day}}=0.025\right)$, na površju pa predvsem počasna $\left(\mathrm{K}^{-\mathrm{day}}=0.0104\right)$. Alogeni detrit $\mathrm{v}$ glavnem sestavljajo kosi lesa (vnos $58.18 \mathrm{~g} / \mathrm{dan})$, sledi listje in manjši rastlinski drobci $(12.76 \mathrm{~g} / \mathrm{dan})$, sadje in semena $(0.0069 \mathrm{~g} / \mathrm{dan})$, živalski ostanki $(0.002 \mathrm{~g} / \mathrm{dan})$ in korenine $(0.001 \mathrm{~g} /$ dan $)$. Največjo raznolikost in število nevretenčarjev smo $\mathrm{v}$ jami zabeležili $\mathrm{v}$ času, ko je vnos alogenih organskih snovi največji.

Ključne besede: jama, pretvorba detrita, pretok energije.

\footnotetext{
${ }^{1}$ Núcleo de Pesquisa em Ciências Biológicas do Centro Universitário de Lavras/Fundação Educacional de Lavras, Rua Padre José Poggel, 506 Centenário, CP.3037, Lavras, MG 37200-000, Brazil, e-mail: souzasilvamarconi@gmail.com

${ }^{2}$ Pós-graduação em Ecologia Aplicada, bolsista CAPES, e-mail: leopoldobernardi@yahoo.com.br

${ }^{3}$ Departamento de Biologia, Centro de Ciências, Universidade Federal do Ceará, Campus do PICI, Fortaleza, Ceará, Brazil, e-mail: wasp@icb.ufmg.br

${ }^{4}$ Laboratório de Ecologia Subterrânea, Departamento de Biologia/Setor de Zoologia, Universidade Federal de Lavras. CP. 3037, CEP 37200-000 Lavras, MG, Brasil, e-mail: drops@dbi.ufla.br
} 


\section{INTRODUCTION}

Caves present very marked environmental characteristics, such as the permanent absence of light and temperature and humidity condition stability (Culver 1982). The permanent absence of light precludes the occurrence of photosynthetic organisms. As a result, primary productivity is relatively infrequent, source of energy appear through chemoautotrophic processes or by the growth of plant roots that access the hypogean environment, as in the case of more near surface caves (Howarth 1983; Jasinska et al. 1996; Sarbu et al. 1996; Hose et al. 2000; Ferreira 2005).

The low primary productivity in the caves causes the available alimentary resources for resident fauna to have, mainly, an allochtonous origin (Culver 1982; Souza-Silva 2003; Simon et al. 2007; Souza-Silva et al. 2007). Therefore, the import of organic resources into caves is through the import of organic matter from the epigean environment through physical (e.g. rivers, runoffs, percolation of water from ceiling or wall) and biological agents (transit of animals between the epigean and hypogean environment) (Culver 1982; Gilbert et al. 1994; Ferreira \& Martins 1999; Simon et al. 2007; Souza-Silva et al. 2007).

The water can transport detritus composed of large pieces of wood, branches, leaves and epigean animal carcasses to the subterranean environment through sinks or openings that exist in the caves (Souza-Silva et al. 2007). Such materials imported by the action of the water frequently form organic deposits which make resources available for the subterranean fauna (SouzaSilva et al. 2007). Furthermore, carcasses and mainly the feces of animals that use the caves as shelters can also accumulate in the subterranean environment becoming important resources for the cave fauna, especially in permanently dry caves (Poulson 1972; Culver 1982; Ferreira \& Martins 1999).

Even having diverse organic matter introduced into the caves, these environments are commonly characterized as oligotrophic, since, usually, the import paths are not efficient and they tend to not transport large amounts of resources (Culver 1982; Simon et al. 2007). Therefore, many organisms that live in caves present specializations usually related to physical limitations and the availability of alimentary resources that exist in these environs (Culver 1982). Being such, the low resource availability becomes a limiting factor for the establishment of countless species in the subterranean ecosystems, causing the subterranean communities to be less complex when compared to those present in the epigean environments (Culver 1982; Howarth 1983; Jasinska et al. 1996). However, exceptions exist, as in the case of caves where the availability of alimentary resources is high. In these cases, the invertebrate communities can present a great number of species allowing more complex trophic networks (Ferreira \& Martins 1999).

Is fundamental to understand the trophic dynamics of different subterranean systems, because these researches are rare and such processes can structure communities in hypogean environment. Among the caves in which studies have been made on some aspect of their trophic dynamics, Movile Cave (Romania), Springs Cave and Organ Cave (USA), Lapa do Córrego dos Porcos and the Caverna Borá IV (Brazil) (Sarbu et al. 1996; Graening 2000; Simon 2000; Souza-Silva 2003; Simon et al. 2007; Souza-Silva et al. 2007) can be cited. Therefore, works that aid towards the understanding of the trophic dynamics of the caves, capable of determining how these processes interfere in the subterranean biodiversity are important, mainly in Brazil, where the number of cavities is quite high and little is known regarding their subterranean communities.

With the intention of evaluating the import rates of detritus into the interior of a limestone cave, as well as the processing dynamics of these alimentary resources and how these processes can interfere with the terrestrial invertebrate community, the following questions were elaborated:

1. What is the monthly organic matter import rate to the interior of the cavity?

2 . What is the monthly organic plant matter processing rate in the cave and in the surrounding epigean environment?

3. Do differences exist between the organic matter processing occurring in the epigean environment and in the hypogean environment?

4. Which organisms are found associated to organic detritus in the cave Lapa da Fazenda Extrema I? 


\section{MATERIALS AND METHODS}

\section{STUDY AREA}

The presented study was performed from August of 2001 to July of 2002 in the Lapa da Fazenda Extrema I (LFE I - UTM: - 374873/8404776 23L) cave that presents 450 meters of linear development. This cave is located on the APA Nascentes of the Rio Vermelho in Mambaí, Goiás, Brazil (CECAV 2007). The main vegetation type in the area is "Cerrado" (Neotropical savannah). However, around the entrance of the cave there exists a prevalence of dry deciduous forest. The dry season occurs between the months of April and September (when the rainfall is less than $50 \mathrm{~mm}$ ) and the rainy season between the months of October and March (when the rainfall can surpass $300 \mathrm{~mm}$ ).

The cave is inserted in a small chunk of limestone and presents four entrances. One of the accesses to the epigean environment corresponds to a sink through which penetrates the Extrema stream, which is perennial. Upstream from this entrance, the water of the stream originates from a small epigean swamp and continues 300 meters to a small depression, surrounded by gallery forest, until reaching the cave. At the end of the depression, the water flows among limestone blocks and reaches the main conduit of the cavity. As such, the interior of the cave receives leaves and large woods of the epigean vegetation. There are hypogean passages where the water flow reaches considerable speed and others where backwaters are formed. The maximum depth is 1 meter. After approximately 200 meters in the cavity, the stream reaches a hypogean sink inaccessible to humans. During the rainy season the partial filling of this drain by various organic materials occurs, and the water level can arise more than 5 meters within the cave. In these periods, the plant detritus can be deposited at places higher and distant from the margin of the hypogean stream.

\section{PROCEDURES}

\section{Characterization of environmental variables}

Six visits were made to the Lapa da Fazenda Extrema I cave during the years of 2001 and 2002. In all visits humidity and temperature measurements of the terrestrial environment were taken besides measurements of $\mathrm{pH}$, temperature, outflow and current speed of the stream.

The physical-chemical data collection points in the aquatic and terrestrial environment were established at the same sites where the organic matter processing (litter bags) experiments were conducted. So, air temperature and air humidity were measured in one site in the epigean and in one site in the middle of the hypogean environment. $\mathrm{pH}$, temperature, outflow and current speed were measurements at two sites in the hypogean aquatic environment.

\section{Import of coarse particulate organic matter}

To evaluate the coarse particulate organic matter import rates (detritus) carried by the water, a contention net was installed close to the entrance downstream from the drainage. The net, made from PVC and of $0.65 \mathrm{~cm}^{2}$ mesh, was installed across the whole traverse extension of the main channel of the hypogean stream. The net was anchored in the walls by a climbing clips and screws.

All the plant and animal material transported by the water into the cave was captured by the contention net inside the cave. This material retained in the net was removed bimonthly, stored in plastic bags and taken to the support base of ICMBio/CECAV in Mambaí (GO) for immediate manual selection of the associated macro-invertebrate fauna. For such, white-bottomed trays, artificial incident light, tweezers and brushes were used. All biological material obtained was conditioned in vials containing $70 \%$ alcohol, for subsequent identification to the accessible taxonomic level and separation in morphospecies.

The collected detritus was fixed in $2 \%$ formol and dried. After drying, the material was separate in the categories "leaves and plant fragments", "seeds and fruits", "roots", "large pieces of wood (greater than $5 \mathrm{~cm}$ )" and "animal carcasses." The quantification of the bimonthly import rate of each category (dry mass measure) was done after a second drying $\left(75^{\circ} \mathrm{C}\right.$ for 48 hours) and weighing on a digital scale $(\max .50 \mathrm{~g}, \mathrm{e}=1 \mathrm{mg}$, $\mathrm{d}=0.1 \mathrm{mg}$ ).

\section{Processing of organic plant matter in the hypogean and epigean environment}

The analysis of the organic plant matter processing rate was conducted using "litter bags" 10x10 cm nylon mesh with textures of $35 \mathrm{~mm}^{2}, 1 \mathrm{~mm}^{2}$ and $0.01 \mathrm{~mm}^{2}$.

The variation in the mesh sizes was intended to include the effect of the performance of invertebrates of different body sizes on the fragmentation of the organic plant matter. In each litter bag, 50 previously weighed plant disks (area $=63.6 \mathrm{~mm}^{2} /$ each disk), removed from intact leaves were placed. Ficus calyptroceras (Moraceae), Piper sp. (Piperaceae), Ilex sp. (Aquifoliaceae), Eschweilera sp. (Lecythidaceae) and Acalypha sp. (Euphorbiaceae) that occur in Brazilian karstic areas were utilized.

The "litter bags" were distributed at 2 aquatic points and 1 terrestrial point inside the cave, besides 1 terrestrial point in the epigean environment. At each point, 
20 litter bags were installed with a mesh opening of $35 \mathrm{~mm}^{2}$, 20 litter bags with $1 \mathrm{~mm}^{2}$ mesh and 20 litter bags with a $0.01 \mathrm{~mm}^{2}$ mesh. In the aquatic environment, each conjunct of litter bags were anchored in the center of each stream channel.

At the epigean and hypogean aquatic points, the current speed $\left(\mathrm{ms}^{-1}\right)$, temperature, $\mathrm{pH}$ and the total outflow $\left(\mathrm{m}^{3} \mathrm{~s}^{-1}\right)$ of the stream were measured bimonthly. At the terrestrial points of the epigean and hypogean environment the humidity and air temperature were measured. In bimonthly collections, the "litter bags" were removed in triplicate (3 litter bags with nesth of $35 \mathrm{~mm}^{2}, 3$ litter bags with $1 \mathrm{~mm}^{2}$ mesh and 3 litter bags with a $0.01 \mathrm{~mm}^{2}$ mesh), to quantify the percentage of mass loss using the formula: $\mathbf{P P}=(\mathbf{P i}-\mathbf{P f}) /(\mathbf{P i})^{\star} \mathbf{1 0 0}$. Where $\mathrm{PP}$ is the percent- age of mass loss, $\mathrm{Pi}$ is the value of the initial mass and Pf is the value of the final mass (Mason 1976).

The analysis of the processing rate was also conducted using an exponential equation model $\mathbf{M}_{\mathrm{t}}=\mathbf{M}_{0} \mathbf{e}^{-\mathrm{Kt}}$ (Oslon 1963; Weider \& Lang 1982). In this model, Mt is the mass at time $t, \mathrm{M}_{0}$ is the initial mass and $\mathrm{K}^{\text {-day }}$ is the inclination of the straight line (mass $\log \mathrm{x}$ time).

Breakdown rates were compared among sites and mesh using a GLM test (generalized linear model).

Immediately after collecting, all litter bags were stored in plastic sacks, and taken to the laboratory for analyses of the invertebrates associated. All biological material obtained was stored in pots containing $70 \%$ alcohol for later identification.

\section{RESULTS}

\section{Environmental characteristics of the cave and epigean surroundings}

The temperature values registered within the cave presented a larger variation than those observed in the external environment. In the epigean environment the highest temperature value was registered in February $\left(26.4^{\circ} \mathrm{C}\right)$ and the lowest in December $\left(22.8^{\circ} \mathrm{C}\right)$. The highest temperature for the hypogean point was registered in October $\left(27.4^{\circ} \mathrm{C}\right)$, and the lowest in June $\left(21.9^{\circ} \mathrm{C}\right)$. The humidity presented its highest value in the hypogean and epigean environments in February ( $81 \%$ and $84 \%$, respectively), the lowest values being registered in October for the hypogean environment (69\%) and in June for the epigean environment (62\%) (Tab. 1).

Tab. 1: Measurements of temperature and humidity in Lapa da Fazenda Extrema I cave and the terrestrial environment.

\begin{tabular}{l|c|c|c|c}
\hline \multirow{2}{*}{ Month } & \multicolumn{2}{|c|}{ Humidity (\%) } & \multicolumn{2}{c}{ Temperature $\left({ }^{\circ} \mathrm{C}\right)$} \\
\cline { 2 - 5 } & Epigean & Hypogean & Epigean & Hypogean \\
\hline October & 69 & 69 & 24.7 & 27.4 \\
\hline December & 83 & 79 & 23.5 & 23.8 \\
\hline February & 84 & 81 & 26.4 & 24.6 \\
\hline April & 73 & 66 & 25 & 25.9 \\
\hline June & 62 & 77 & 22.8 & 21.9 \\
\hline
\end{tabular}

The variations in the values of the water outflow and current speed were quite accentuated, the highest values being found in October, in the beginning of the rainy period (outflow $0.694 \mathrm{~m} \mathrm{~m}^{3} \mathrm{~s}^{-1}$ and current $0.67 \mathrm{~ms}^{-1}$ ). The lowest outflow value was registered in June during the dry season $\left(0.177 \mathrm{~m}^{3} \mathrm{~s}^{-1}\right)$, and the lowest current speed values were registered in June in the dry season and February, at the end of the rain y season $\left(0.21 \mathrm{~ms}^{-1}\right)$ (Tab. 2).

Tab. 2: Values of Outflow and water Stream Speed in the hypogean creek, Lapa da Fazenda Extrema I.

\begin{tabular}{l|c|c}
\hline Month & Outflow $\left(\mathrm{m}^{3} \mathrm{~s}^{-1}\right)$ & Current Speed $\left(\mathrm{ms}^{-1}\right)$ \\
\hline October & 0.694 & 0.67 \\
\hline December & 0.458 & 0.27 \\
\hline February & 0.362 & 0.21 \\
\hline April & 0.627 & 0.42 \\
\hline June & 0.177 & 0.21 \\
\hline
\end{tabular}

The $\mathrm{pH}$ of the water was shown slightly acidic, presenting small variations during the year. The first collection site was where the smallest oscillation in the $\mathrm{pH}$ was observed, that varied between 5.92 and 6.65. However, the second collection site presented a slightly higher oscillation, with values that varied between 5.83 and 6.85 . The water temperature was also shown quite stable during the whole year, having varied between $22.7^{\circ} \mathrm{C}$ and $24.0^{\circ} \mathrm{C}$ at the first sampling site and $22.7^{\circ} \mathrm{C}$ and $23.4^{\circ} \mathrm{C}$ at the second sampling point (Tab. 3).

During the periods of more intense rains, between the months of October to March, major floods occurred in the cave stream that increases its flow suddenly. During these events the river acquires great transport power, carrying large amounts of detritus and sediments (Fig. 1). 
Tab. 3: Values of $p H$ and water temperature in the hypogean creek, Lapa da Fazenda Extrema I.

\begin{tabular}{l|c|c|c|c}
\hline \multirow{2}{*}{ Month } & \multicolumn{2}{|c|}{$p H$} & \multicolumn{2}{c}{ Temperature $\left({ }^{\circ} \mathrm{C}\right)$} \\
\cline { 2 - 5 } & Aquatic I & Aquatic II & Aquatic I & Aquatic II \\
\hline October & 6.20 & 6.85 & 22.8 & 22.8 \\
\hline December & 5.92 & 5.83 & 22.7 & 22.8 \\
\hline February & 6.65 & 6.56 & 24.0 & 23.4 \\
\hline April & 6.30 & 6.22 & 22.8 & 22.7 \\
\hline June & - & - & - & - \\
\hline
\end{tabular}

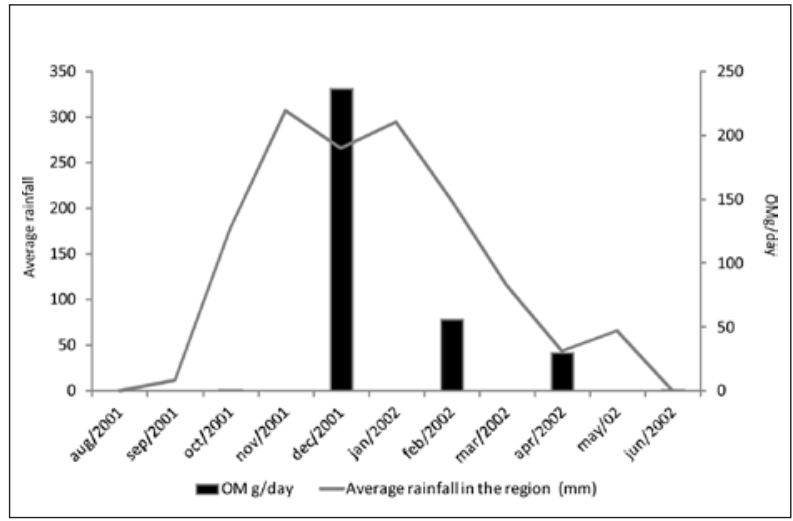

Fig. 1: Import of detritus by the creek, into the Lapa da Fazenda Extrema I cave and the mean precipitation in the region from August 2001 to July 2002.

\section{Import of detritus to the cave interior}

The organic plant matter was the resource most carried to the interior of the cave. Large wood $(5-80 \mathrm{~cm})$ fragments made up the most transported plant detritus, corresponding to 58.18 grams of daily importation into the cavity. Besides that, leaves and fragmented material $(12.76 \mathrm{~g} /$ day $)$, fruits and seeds $(0.069 \mathrm{~g} /$ day $)$, animal carcasses $(0.002 \mathrm{~g} /$ day $)$ and roots $(0.001 \mathrm{~g} /$ day $)$ were also transported (Fig. 1 \& Tab. 4).

The highest rate of detritus imported to the hypogean environment ( $236.33 \mathrm{~g} /$ day) occurred between October and December, coinciding with the period in which the highest amount of rain in the area occurs. The low-

Tab. 4: Bimonthly measurements of detritus retention of imported via the stream to the Lapa da Fazenda Extrema I cave (grams/day).

\begin{tabular}{|c|c|c|c|c|c|c|c|}
\hline \multicolumn{8}{|c|}{ Categories of detritus } \\
\hline Retention Period & $\begin{array}{l}\text { Days of } \\
\text { Retention }\end{array}$ & $\begin{array}{c}\text { Fruits } \\
\text { and } \\
\text { Seeds }\end{array}$ & $\begin{array}{l}\text { Leaves } \\
\text { and } \\
\text { Fragments }\end{array}$ & $\begin{array}{l}\text { Animal } \\
\text { carcasses }\end{array}$ & $\begin{array}{l}\text { Large } \\
\text { piece } \\
\text { woods }\end{array}$ & Roots & Total \\
\hline $\mathrm{Ag} / 01-\mathrm{Oct} / 01$ & 62 & 0.005 & 0 & 0 & 0.111 & 0 & 0.116 \\
\hline Oct/01-Dec/01 & 74 & 0.005 & 34.73 & 0.007 & 201.04 & 0.007 & 235.79 \\
\hline Dec/01-Feb/02 & 66 & 0.3 & 6.94 & 0.0034 & 48.63 & 0 & 55.87 \\
\hline Feb/02-Apr/02 & 73 & 0.029 & 15.75 & 0 & 14.38 & 0 & 30.16 \\
\hline Mar/02-Jun/02 & 54 & 0 & 0.372 & 0 & 0 & 0 & 0.37 \\
\hline
\end{tabular}

est rates were registered between August and October $(0.117 \mathrm{~g} /$ day $)$ and between May and June $(0.372 \mathrm{~g} /$ day $)$, coinciding with the periods of the lowest amounts of rain in the area (Fig. $1 \&$ Tab. 4).

\section{PROCESSING OF PLANT DETRITUS IN THE CAVE AND EPIGEAN SURROUNDINGS}

\section{Terrestrial environment}

All of the "litter bags" presented a mass loss, in the first 62 days, superior to $46 \%$ in relation to their initial mass. However, the disks exposed to the processing in the epigean environment presented a higher mass loss than those exposed in the hypogean environment (superior to $54.43 \%$ of their initial mass) (Tab. 5).

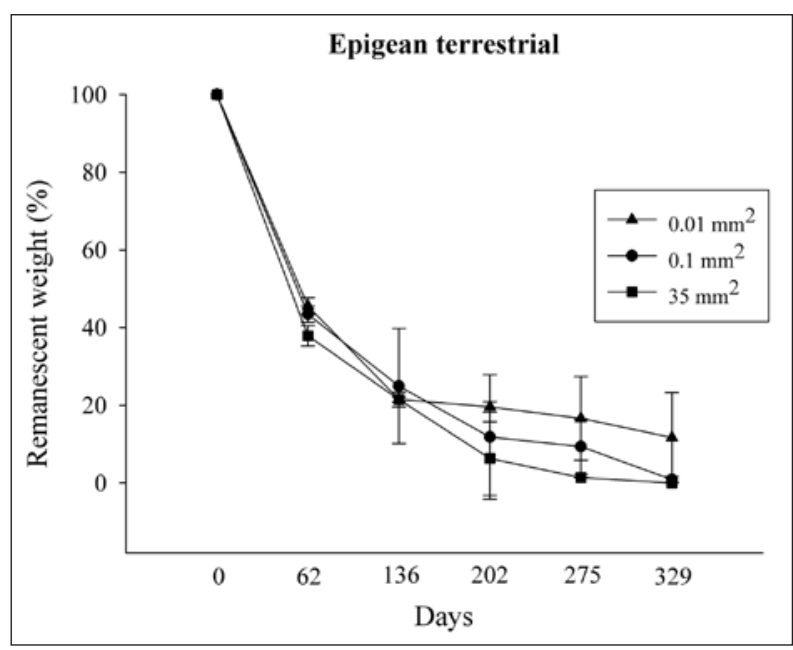

Fig. 2: Percentage of mass loss of organic plant matter exposed to processing in the terrestrial epigean environment of the Lapa da Fazenda Extrema I cave.

The highest initial mass loss (62.1\% in 62 days of exposure) was registered in the terrestrial epigean environment "litter bags" with larger mesh opening (mesh size $35 \mathrm{~mm}^{2}$ ). At this site the highest processing rate was also registered for the terrestrial environment $\left(\mathrm{K}^{\text {-day }}=0.0104\right)$.

The lowest initial mass loss ( $46 \%$ in 62 days of exposure) was registered in the hypogean environment "litter bags" of larger texture (mesh size $35 \mathrm{~mm}^{2}$ ). At this site the lowest processing rates were also registered $\mathrm{K}^{- \text {day }}(0.0088)$, the processing being considered as slow (Figs. $2 \& 3$, Tab. 5).

In all of the "litter bags", at 329 days of exposure, there was a processing rate supe- 
rior to $93 \%$ of the initial mass, all the organic matter in the epigean environment "litter bags" being processed. However, at the end of the experiment, the "litter bags" with mesh size $0.01 \mathrm{~mm}^{2}$ of the hypogean environment presented a lower loss of organic plant matter $(34.623 \%$ of the initial mass) (Figs. $2 \& 3$, Tab. 5).

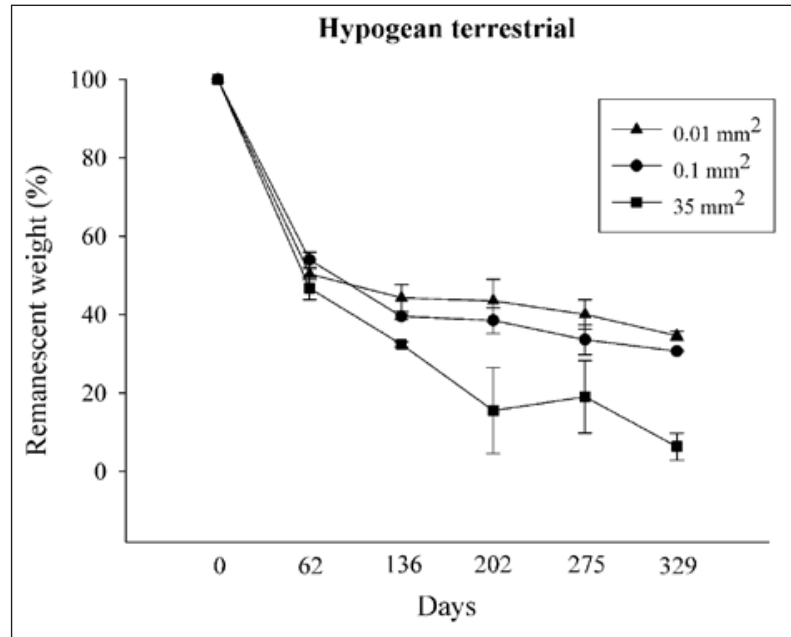

Fig. 3: Percentage of mass loss of organic plant matter exposed to processing in the terrestrial hypogean environment of the Lapa da Fazenda Extrema I cave.

The processing of organic matter did not present significant differences between the epigean and hypogean environments.

The mesh of the litter bags in the terrestrial hypogean and epigean environment did not presented significantly differences.

\section{Aquatic environment}

The plant disks that were exposed to the processing in the hypogean stream presented a moderate mass loss rate. At the first aquatic collection point, after 62 days there was, on average, $86.04 \%$ loss of the initial mass. However, at the second aquatic collection point, after the same period, $83.44 \%$ of the plant matter had been processed (Tab. 6).

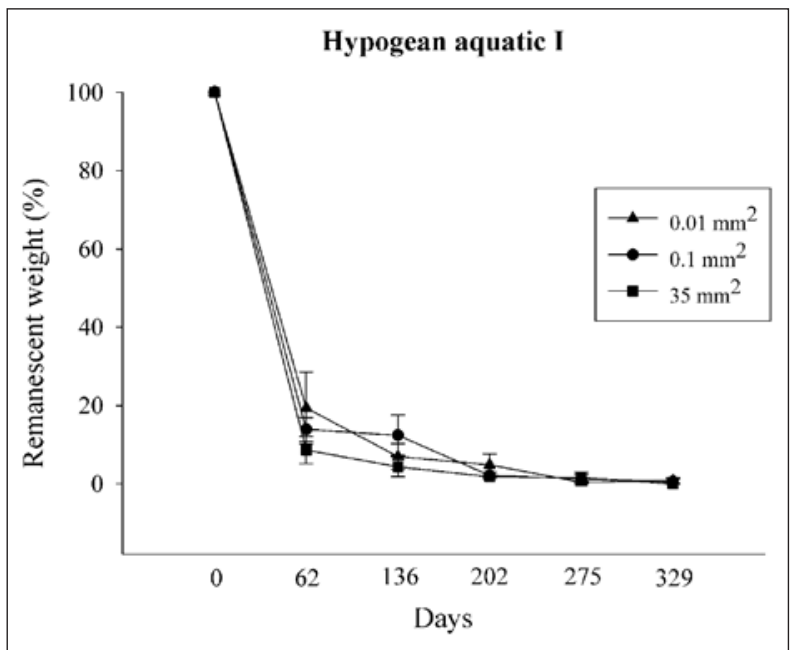

Fig. 4: Percentage of mass loss of organic plant matter exposed to processing in the aquatic hypogean aquatic environment 1 of the Lapa da Fazenda Extrema I cave.

The loss of final mass was superior in the "litter bags" of mesh size $35 \mathrm{~mm}^{2}$, in the hypogean environment as well as in the epigean. After 329 days, any organic matter hardly remained in the litter bags. The lowest mass loss rate was registered in the "litter bags" of mesh size $0.01 \mathrm{~mm}^{2}$ in the aquatic environment 1 , where, after 329 days, an average of $0.33 \%$ of the initial organic matter remained $(K=0.0173)$ (Figs. 4 \& 5, Tab. 6).

The mesh of the litter bags in the aquatic hypogean environment did not presented significantly differences.
Tab. 5: Mean processing rate (process use) of organic plant matter in the terrestrial and aquatic in epigean and hypogean environments of the Lapa da Fazenda Extrema I.

\begin{tabular}{l|c|c|c|c|c}
\hline Site & Mesh & $\boldsymbol{K}$ & Processing & Inicial Mass $(\boldsymbol{g})$ & Final Mass $(\boldsymbol{g})$ \\
\hline Terrestrial Epigean & $35 \mathrm{~mm}^{2}$ & 0.0086 & Slow & 0.64 & 0.15 \\
\hline Terrestrial Epigean & $1 \mathrm{~mm}^{2}$ & 0.0084 & Slow & 0.63 & 0.12 \\
\hline Terrestrial Epigean & $0.01 \mathrm{~mm}^{2}$ & 0.0104 & Moderate & 0.6 & 0.08 \\
\hline Terrestrial Hypogean & $35 \mathrm{~mm}^{2}$ & 0.0099 & Slow & 0.62 & 0.26 \\
\hline Terrestrial Hypogean & $1 \mathrm{~mm}^{2}$ & 0.0088 & Slow & 0.61 & 0.24 \\
\hline Terrestrial Hypogean & $0.01 \mathrm{~mm}^{2}$ & 0.0079 & Slow & 0.59 & 0.14 \\
\hline Aquatic Hypogean I & $35 \mathrm{~mm}^{2}$ & 0.017 & Moderate & 0.64 & 0.006 \\
\hline Aquatic Hypogean I & $1 \mathrm{~mm}^{2}$ & 0.020 & Moderate & 0.66 & 0.012 \\
\hline Aquatic Hypogean I & $0.01 \mathrm{~mm}^{2}$ & 0.017 & Moderate & 0.62 & 0 \\
\hline Aquatic Hypogean II & $35 \mathrm{~mm}^{2}$ & 0.025 & Moderate & 0.66 & 0.004 \\
\hline Aquatic Hypogean II & $1 \mathrm{~mm}^{2}$ & 0.025 & Moderate & 0.62 & 0.004 \\
\hline Aquatic Hypogean II & $0.01 \mathrm{~mm}^{2}$ & 0.023 & Moderate & 0.56 & 0 \\
\hline
\end{tabular}

Composition and richness of invertebrates

During the bimonthly collections conducted for the accumulation of organic matter retained, in the contention net and in the litter bags 171 species were found distributed in at least 44 families of the following taxa: Mesostigmata, Trombidiforme, Sarcoptiforme, Pseudoscorpiones, Araneae, Opiliones, Chilopoda, Polydesmida, Collembola, Blattodea, Coleoptera, Diptera, Psocop- 
Tab. 6: Composition, abundance and richness of invertebrates collected in the accumulation of organic matter in Lapa da Fazenda Extrema I.

\begin{tabular}{|c|c|c|c|c|c|c|c|c|c|c|c|}
\hline \multirow{2}{*}{ Taxon } & \multirow{2}{*}{ Family } & \multicolumn{2}{|c|}{ Oct/2001 } & \multicolumn{2}{|c|}{$\mathrm{Dec} / 2001$} & \multicolumn{2}{|c|}{ Feb/2002 } & \multicolumn{2}{|c|}{ Apr/2002 } & \multicolumn{2}{|c|}{ Jun/2002 } \\
\hline & & $R$ & $A b$ & $R$ & $A b$ & $R$ & $A b$ & $R$ & $A b$ & $R$ & $A b$ \\
\hline \multirow[t]{2}{*}{ Mesostigmata } & Macrochelidae & & & 1 & 16 & & & & & & \\
\hline & Laelapidae & & & 1 & 3 & & & 1 & 1 & & \\
\hline \multirow[t]{2}{*}{ Trombidiforme } & Cunaxidae & & & & & & & 1 & 1 & & \\
\hline & Trombidiidae & & & 1 & 2 & & & & & & \\
\hline Sarcoptiforme & $\begin{array}{ll}-- \\
--\end{array}$ & 1 & 3 & 1 & 2 & & & & & & \\
\hline Pseudoscorpiones & --- & & & 4 & 6 & & & & & 1 & 1 \\
\hline \multirow[t]{10}{*}{ Araneae } & Theridiidae & & & 5 & 6 & 1 & 1 & 1 & 2 & 1 & 2 \\
\hline & Clubionidae & & & 1 & 4 & 1 & 1 & & & & \\
\hline & Salticidae & & & 1 & 2 & 1 & 1 & & & & \\
\hline & Lycosidae & & & 2 & 3 & 1 & 1 & & & & \\
\hline & Linyphidae & & & 1 & 1 & & & & & & \\
\hline & Araneidae & & & 1 & 1 & & & & & & \\
\hline & Ctenidae & & & & & & & & & 1 & 1 \\
\hline & Sicariidae & & & & & & & & & 1 & 2 \\
\hline & Salticidae & & & 1 & 2 & 1 & 1 & & & & \\
\hline & Pholcidae & & & & & & & & & 1 & 1 \\
\hline \multirow[t]{2}{*}{ Opiliones } & Gonyleptidae & & & 1 & 1 & & & & & & \\
\hline & Cosmetidae & & & & & & & & & 1 & 1 \\
\hline Chilopoda & --- & & & 1 & 1 & & & & & & \\
\hline Polydesmida & Oniscodesmidae & & & 1 & 3 & & & & & & \\
\hline \multirow[t]{2}{*}{ Collembola } & Neanuridae & & & 3 & 115 & 1 & 1 & & & & \\
\hline & Sminthuridae & & & 1 & 1 & & & & & & \\
\hline Blattodea & --- & & & 2 & 4 & & & 2 & 3 & & \\
\hline Coleoptera & Larvae & 1 & 2 & 31 & 127 & 6 & 14 & 7 & 11 & 1 & 1 \\
\hline & Sthaphylinidae & & & 14 & 87 & 5 & 17 & 4 & 4 & & \\
\hline & Dryopidae & 1 & 1 & 2 & 15 & 1 & 1 & & & & \\
\hline & Carabidae & & & 5 & 11 & 2 & 4 & & & & \\
\hline & Scarabaeidae & & & 3 & 6 & & & 1 & 1 & & \\
\hline & Pselaphidae & & & 5 & 27 & 1 & 6 & 1 & 1 & 1 & 2 \\
\hline & Phalacridae & & & 1 & 13 & 1 & 2 & & & 1 & 1 \\
\hline & Ptylodactilidae & & & & & 2 & 3 & & & & \\
\hline & Coccinellidae & & & 1 & 1 & & & & & & \\
\hline Diptera & Larvae & 2 & 3 & & & 1 & 2 & & & 1 & 1 \\
\hline & Stratiomyidae (larvae) & & & 4 & 13 & & & & & & \\
\hline & Chironomidae (larvae) & 1 & 1 & & & 1 & 9 & & & & \\
\hline & Tipulidae & & & & & 1 & 2 & & & & \\
\hline & Ceratopogonidae & & & & & 1 & 3 & & & & \\
\hline Isoptera & --- & & & 1 & 2 & & & & & & \\
\hline Psocoptera & Pseudocaeciliidae & & & & & 1 & 1 & & & & \\
\hline Lepidoptera & Larvae & & & 5 & 5 & & & 2 & 2 & & \\
\hline & Noctuidae & & & & & & & & & 1 & 1 \\
\hline Ephemeroptera & --- & 1 & 2 & & & & & & & & \\
\hline Plecoptera & Perlidae & 1 & 2 & & & & & & & & \\
\hline Trichoptera & Hydropsychidae & & & 1 & 1 & & & & & & \\
\hline & Leptoceridae & 2 & 3 & & & 1 & 3 & & & & \\
\hline Orthoptera & --- & & & 1 & 2 & & & 2 & 2 & & \\
\hline & Acrididae & & & 1 & 2 & & & & & & \\
\hline Hemiptera & --- & & & 1 & 10 & & & & & & \\
\hline & Cydnidae & & & 14 & 41 & 2 & 2 & & & & \\
\hline & Veliidae & & & 4 & 6 & & & & & & \\
\hline & Hebridae & & & 2 & 10 & & & & & & \\
\hline & Hydrometridae & & & 1 & 1 & & & & & & \\
\hline & Belostomatidae & 1 & 1 & & & & & & & & \\
\hline & Naucoridae & & & & & & & 1 & 1 & & \\
\hline Thysanoptera & --- & & & 1 & 1 & & & & & & \\
\hline Hymenoptera & --- & & & 2 & 2 & & & & & & \\
\hline & Formicidae & & & 11 & 294 & 4 & 81 & 4 & 10 & 1 & 1 \\
\hline Nematoda & --- & & & 1 & 1 & & & & & & \\
\hline Annelida & --- & & & 1 & 3 & & & & & & \\
\hline Total & & 11 & 18 & 142 & 857 & 36 & 156 & 27 & 39 & 12 & 15 \\
\hline
\end{tabular}




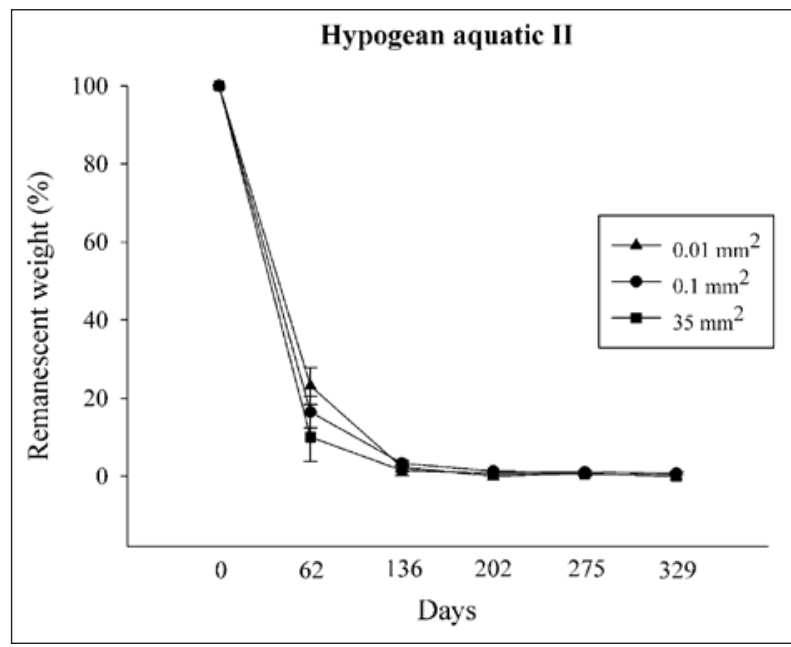

Fig. 5: Percentage of mass loss of organic plant matter exposed to processing in the aquatic hypogean aquatic environment 2 of the Lapa da Fazenda Extrema I cave.

tera, Isoptera, Lepidoptera, Ephemeroptera, Plecoptera, Trichoptera, Orthoptera, Thysanoptera, Hemiptera, Hymenoptera, Nematoda and Annelida (Tab. 6).

Coleoptera was the group that presented the highest richness, with 70 species distributed in at least 8 families. Hymenoptera was the most abundant order, with 387 individuals belonging mainly to the family Formicidae.

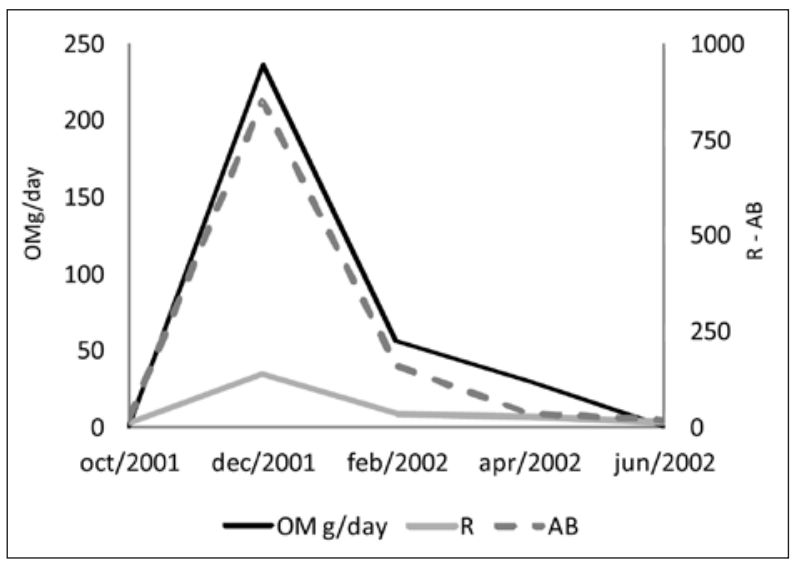

Fig. 6: Rate of organic matter (OM) import per month (grams/ day), richness of invertebrates $(R)$ and abundance of invertabrates $(A B)$.

The invertebrates present in the organic matter retained by the contention nets and in the litter bags presented their highest richness and abundance in the peak of the rainy period (December), when 142 species and a total of 857 individuals were observed. The lowest richness was found at the end of the dry period (October) where only 11 species and a total of 18 individuals were observed (Tab. 6 \& Fig. 6).

\section{DISCUSSION}

\section{IMPORT OF ORGANIC MATTER CARRIED BY THE CREEK}

Organic resources must be imported to underground ecosystems, whether by water (rainwater or rivers), the wind, or organisms which transit between the hypogean and epigean environments (e.g. bats, crickets, and birds) (Culver 1982; Howarth 1983; Edington 1984; Souza-Silva 2005). Although it is essential to the role understanding the hypogean ecosystems, studies concerning trophic dynamics in caves are rare (Sarbu et al. 1996; Graening 2000; Simon 2000; Souza-Silva 2003; Simon et al. 2007; Souza-Silva et al. 2007). In Brazil, only three studies had been conducted up to the moment, two of them had been made in the same region of the Lapa da Fazenda Extrema I. However, the other studies have shown some different results, probably due to the geomorphology of the caves, which imposed some different abilities to the importation processes of the organic detritus.

In the Lapa da Fazenda Extrema I (LFE I) cave a clear season variation exists in the imported of organic matter to the hypogean environment, as observed in other cavities in this same area (Souza-Silva 2003). The rainy period (October to March) is characterized by presenting transport of a great amount of organic detritus to the interior of the caves, while in the dry period (April to September) is noticed that the amount of transported detritus reduces significantly. In spite of the period of nutrient flow being similar in the caves LFE I, Lapa do Córrego dos Porcos (LCP) and Borá IV, the components involved in the dynamics, transport and retention of detritus are different, causing the amount and the quality of the material transported to the interior of each of the subterranean systems to be also distinct (Souza-Silva 2003).

One of the main determinants of the amount of organic detritus transported to the LFE I interior is the topographical conformation of the area upstream from the drainage. The LFE I entrance is located at the end of a gently sloped wide depression. This depression not only directs the waters of the Extrema stream to the 
cavity, but also favors the reception and surface drainage of the water originating from a wide area to the stream, during the rainy periods. Furthermore, around the stream, a riparian deciduous vegetation is observed. Such vegetation contains a great amount of plant species that lose their leaves in the dry periods, which provides a large litter accumulation during the dry season, as occurs in other Brazilian karstic areas (Brina 1998). As a result, when there is a high volume of rain in the area, the stream overflows and its waters capture plant detritus that has been accumulating at places far from its normal bed. All material captured is transported towards the cavity. As evidence of this efficient transport, it was observed that the total mass of the organic detritus that penetrated in LFE I was 96 times higher than the amount observed for the Borá IV Cave and 25 times higher than in the Lapa do Córrego dos Porcos, both located in the same area (Souza-Silva 2003; Souza-Silva et al. 2007). These last two are inserted in a relief that hinders the contribution of organic plant matter to the subterranean environment.

The organic matter carried by the water to the interior of the cavity was mainly composed of plant detritus (large pieces of wood, leaves, roots and dry fruits), as also observed at other caves of the area (Souza-Silva 2003; Souza-Silva et al. 2007). However, unlike the other cavities, in which the small detritus derived from leaves and fragmented material were the most representative, in LFE I a large part of transported material was made up of large fragments, such as pieces of woods. Such large pieces of wood were transported to the interior of the cave in the rainiest months, and they contributed to a large part of the total biomass material collected in the contention nets.

The types of plant detritus (fragments, large pieces of wood, roots, etc) that penetrate the caves can depend not only on the volume of rains of a given area, but also of the topographical irregularities existent at the places through which the contribution of these resources occur. Thus, when the cave entrances (or other areas that give access to the hypogean environment) present barriers (e.g. fallen rocks), these can act as "filters", retaining the organic matter. Besides, such "barriers", water flow can fragment the material that is carried to caves. This fragmentation type was also observed at the Borá IV cave by Souza-Silva and collaborators (2007) and in the Lapa do Córrego dos Porcos by Souza-Silva (2003), and it was responsible for the differences of the material type found in LFE I, that has an entrance free from obstacles.

The siphon present at the end of the LFE I conduit differences in the transport dynamics and mainly the retention of detritus in the hypogean environment. During strong rains, the siphon does not allow outflow for all the water that penetrates the cave, forming a lake of more than $20 \mathrm{~m}$ of extension, which floods a great portion of the final conduits of the cavity. During these events, material such as leaves and large pieces of wood are deposited on the floor of the cave in places that are up to 10 meters away from the "normal" bed of the hypogean stream. When the entrance of water in the cave decreases, the drainage through the siphon causes the stream to return to its normal bed. During the dry seasons or when the rains are not intense, deposited detritus on the cave soil serve as important food for the invertebrate fauna in hypogean environment.

\section{THE PROCESSING OF ORGANIC PLANT MATTER}

In short, what happens with the organic plant matter is a rapid mass loss over the initial days, due to the processing of soluble materials (carbohydrates and proteins), followed by a slower process due to the presence of higher rates of matter of difficult leaching and processing (lignin, cellulose and fats) (Wieder \& Lang 1982). The mass loss speed of the material exposed in the aquatic environment tends to be higher than that observed in the terrestrial environment. Such a fact occurs mainly from the leaching and the abrasive force of the water, besides the mechanical fragmentation the invertebrates undergo, which favors the fast processing of the detritus (Pomps et al. 1996).

The plant detritus processing stages in the aquatic and terrestrial environments of LFE I are similar to those observed by Souza-Silva (2003) in the Lapa do Córrego dos Porcos (LCP), by Souza-Silva and collaborators (2007) in the Borá IV Cave, this studies was conducted in the same region. However, the processing rates of detritus found in the aquatic environment in three Brazilian caves (LFE I, LCP and Borá IV) were superior to almost all the rates observed by Simon \& Benfield (2001) in Organ Cave (Virgina, USA). The processing rates found in Organ Cave varied between 0.0033 and 0.0259 , while in the Brazilian caves values that varied between 0.017 and 0.598 were observed. Differences in the biotic and abiotic conditions of these caves might have determined the variations observed. The water temperature registered in Organ Cave is quite inferior (varying between $11.6^{\circ} \mathrm{C}$ and $9.3^{\circ} \mathrm{C}$ ) to the temperatures registered in the waters of the LFE I, LCP and Borá IV cave, which varied between $21.0^{\circ} \mathrm{C}$ and $26.0^{\circ} \mathrm{C}$. Furthermore, the richness of aquatic invertebrates (that act in the processing processes) found by Simon \& Benfield (2001), was always lower to that found in the Brazilian caves. In Organ Cave, the point where the highest organic plant matter processing rates were observed presented 11 species, which corresponded 
to the highest richness found. In the Brazilian caves, the number of species found associated with the litter bags (Borá IV = 14 ssp, LFE I = 21 ssp. and LCP = 39 ssp.) was always higher to that found in Organ Cave.

Differences among the mass loss rates in the "litter bags" do not only occur among different caves, but could be observed at the same cave. These rates can vary according to the characteristics of the locals where the organic material is exposed to the processing. In the LFE I terrestrial environment, the processing rates were slower than those registered in the aquatic environment of the same cave. The processing of organic detritus in streams is attributed to a group of four steps that act, and many times do not occur in the intensity in the terrestrial environment. Such steps include the leaching of soluble organic compounds, the abrasion and fragmentation by water action, microbial processing and the fragmentation and processing by invertebrates (Simon \& Benfield 2001).

Differences were also found in the processing rates between the terrestrial epigean and hypogean environments. Those differences can be attributed to the high humidity and temperature values observed in the hypogean environment (and their lower variations) compared to those observed in the surrounding epigean environment. The lack of favorable conditions, of which low litter humidity stands out, can inhibit the colonization by the fauna and reduce the detritus consumption speed (Goley et al. 1978; Wieder \& Lang 1982; Humphreys 1991). Furthermore, waters that drip from speleothems and/or run down the walls can accelerate the processes even more when acting on the leaching of the more soluble compounds.

\section{THE INVERTEBRATE COMMUNITIES}

The richness of invertebrates found in LFE I (171 spp.), was much larger than that observed in other caves of the area. Motta and collaborators (2001), working with fauna survey of five caves in the area, and found on average 24 species. In more detailed works, Souza-Silva (2003) found 168 species in LCP and Souza-Silva and collaborators (2007) found 39 species in Borá IV cave, in two caves sampled in the same area.

The accumulation of organic matter in the contention nets in the proximities of the LFE I entrance might have attracted a large number of species, since this organic matter serves as shelter and food for many invertebrates. Besides, organisms that eventually were brought by the current could survive in the detritus present in the contention net. The highest invertebrate richness and abundance values coincide exactly with the high amount of organic matter accumulated in the contention net.

The invertebrates associated in the organic matter in the nets are mainly shredders organisms. Among them we can mention the beetles as well as the dipterans, mites, ants, some springtails and moth larvae that directly consume or fragment the organic plant matter. Plus, some predators were also found, such as spiders, hemipterans, beetles and some acarids. The accumulations of organic matter in the cave environments can work as systems susceptible to colonization, mainly when considering that the caves are sites characterized by low amount of nutrients (Culver 1982).

\section{FINAL CONCLUSIONS}

The understanding of the dynamics of the production pathways and flow of organic matter of any ecosystem is fundamental for the conservation of its biodiversity, since these two processes can be strongly linked (Hooper et al. 2000). However, in Brazilian caves, research with the intention of elucidating the operation of the trophic dynamics of those systems is still very scarce. Brazil has invested in research that aids towards a better understanding of these questions only in recent years. Souza-Silva (2003) was the first to accomplish studies with the intention of better understanding the processes that act in the transport and processing of the organic matter that penetrates in the Brazilian caves. Later came the works of Souza-Silva et al. (2007) and Silva (2008), besides the work presented here. After decades of studies on the Brazilian cave fauna, still very little is known regarding a theme that has been showing a great importance towards the understanding and the conservation of the subterranean systems. Therefore, it is of extreme importance that new studies in other diverse areas are developed so that the Brazilian speleological patrimony, which is currently under threat, can be best understood and conserved.

\section{ACKNOWLEDGEMENTS}

ECMVS, IBAMA/CECAV (José A. Motta), CAPES, FAPEMIG, CNPq and the US Fish \& Wildlife Service for assistance with the execution of the research. R. P. Mar- tins is a $1 \mathrm{~B}$ researcher of the Conselho Nacional de Pesquisa $(\mathrm{CNPq}-\mathrm{Brasil})$. 


\section{REFERENCES}

Allan, J.D., 1995: Stream ecology: Structure and function of running waters.- Alden Press, pp. 377, Oxford.

Brina, A.E., 1998: Aspectos da dinâmica da vegetação associada a afloramentos calcários na APA carste de Lagoa Santa, MG.- Msc thesis. Universidade Federal de Minas Gerais/Pós-Graduação em Ecologia Conservação e Manejo da Vida Silvestre, Belo Horizonte, pp. 105.

Culver, D.C., 1982: Cave Life.- Harvard University and Cambridge Press, pp. 189, Massachusetts.

Edington, M., 1984: Biological observations on the Ogbuike cave system, Anambra state, Nigeria.- Studies in Speleology, 5, 31-38.

Ferreira, R.L. \& R.P. Martins, 1999: Trophic structure and natural history of bat guano invertebrate communities, with special reference to Brazilian caves. Tropical Zoology, 12, 231-252.

Ferreira, R.L., 2004: A medida da complexidade biológica, e suas aplicações na ecologia e manejo de sistemas subterrâneos.- $\mathrm{PhD}$ thesis. Universidade Federal de Minas Gerais/Pós-Graduação em Ecologia Conservação e Manejo da Vida Silvestre, Belo Horizonte, pp. 168.

Ferreria, R.L., 2005: A vida subterrânea nos campos ferruginosos.- O Carste, 3, 17, 106-115.

Gallas, J., Bednarz, T., Dummicka, A., Starzecka \& K. Wojan, 1996: Litter decomposition in a mountain cave water.- Arch. Research, 36, 3, 459-469.

Graening, G.O., 2000: Ecosystem dynamics of an Ozark cave.- Ph.D thesis. University of Arkansas, pp. 99.

Gilbert, J., Danielpol, D.L. \& J.A. Stanford, 1994: Groundwater ecology.- Academic Press Limited, pp. 571, San Diego.

Gillieson D., 1996: Caves processes, development and management.- Blackwell Publishers Inc., pp. 324, Cambridge.

Goley, F.B., McGrinnin, J.T., Clements, R.G., Child, G.I. \& M.J. Duever, 1978: Ciclagem de Minerais em um Ecossistema de Floresta Tropical.- Editora Universitária, pp. 256, São Paulo.

Holsinger, R. \& D.C. Culver, 1988: The invertebrate cave fauna of Virginia and a part of eastern Tennessee: zoogeography and ecology.- Brimleyana, 14, 1-162.

Howarth, F.G., 1983: Ecology of cave arthropods.- Annual Rewiew of Entomology, 28, 365-389.

Humphreys, W.F., 1991: Experimental re-establishment of pulse-driven population in a terrestrial troglobite community.- Journal of Animal Ecology, 60, 609-623.
Jasinska, E.J., Knott, B. \& A.J. McComb, 1996: Hot mats in groundwater: a fauna-rich cave habitat.- Journal of American Benthological Society, 15, 4, 508-519.

Mason, C.F., 1976: Ciclos Biogeoquímicos, Decomposição.Editora Pedagógica e Universitária, Vol. 18, pp. 66, São Paulo.

Oslon, J.S., 1963: Energy storage and the balance of producers and decomposers in ecological systems.Ecology, 44, 2, 322-331.

Palmer, M.A., Covich, C.P., Lake, S., Biro, P., Brooks, J.J., Cole, J., Dahim, C., Gibert, J., Gpoedkoop, W., Martens, K., Verhoeven, J. \& W.J.V. Bund, 2000: Linkages between aquatic sediment biota and life above sedments as potential drivers of biodiversity and ecological processes.- BioScience, 50, 12, 1062 1075.

Poulson, L.T., 1972: Bat guano ecosystems.- Bulletin of National Speleological Society, 34, 2, 55-59.

Sarbu, S.M., Kane, T.C. \& B.K. Kinkle, 1996: A chemoautotrophically basead cave ecosystem.- Science, 272, 1953-1955.

Silva, A.P.B., 2008: Enriquecimento trófico em ambientes subterrâneos e suas aplicações para a conservação da biodiversidade de invertebrados aquáticos.- Msc thesis. Universidade Federal Lavras/Pós-Graduação em Ecologia Aplicada, Lavras, pp. 153.

Simon, K.S., 2000: Organic matter dynamics and trofic structure in Karst groundwater.- PhD thesis. Faculty of the Virginia Polythecnic Institute and State University, pp. 91.

Simon, K.S., \& E.F. Benfield, 2001: Leaf and wood breakdown in cave streams.- Journal of North American Benthological Society, 20, 4, 550-563.

Simon, K.S. \& E.F. Benfield, 2002: Ammonium retention and whole-stream metabolism in caves streams.Hydrobiologia, 482, 31-39.

Simon, K.S., Pipan, T. \& D.C. Culver, 2007: A conceptual model of the flow and distribution of organic carbon in caves.- Journal of Cave and Karst Studies, 69, 2, 279-284.

Souza-Silva, M. 2003: Dinâmica de disponibilidade de recursos alimentares em uma caverna calcária.- $\mathrm{PhD}$ thesis. Universidade Federal de Minas Gerais/PósGraduação em Ecologia Conservação e Manejo da Vida Silvestre, Belo Horizonte, pp. 76.

Souza-Silva, M., Ferreira, R.L., Bernardi, L.F.O. \& R.P. Martins, 2007: Importation and processing of organic detritus in linestone cave.- Espeleo-Tema, 19, $31-46$. 
Trajano, E., 2000: Cave faunas in the atlantic tropical rain Forest: composition, ecology and conservation.- Biotropica, 32, 4b, 882-893.

Weider, R.K. \& G.E. Lang, 1982: A critique of the analytical methods used in examining decomposition data obtained from litter bags.- Ecology, 63, 6, 1636-1642.
Webster, J.R., Benfield, E.F., Ehrman, T.P., Schaeffer, M.A., Tank, J.L., Hutchens, J.J. \& D.J. D’Angelo, 1999: What happens to allochthonous material that falls into streams? A synthesis of new and published information from Coweeta.- Freshwater Biology, 41, 687-705.

Zar, J.H., 1996: Biostatistical analysis, $3^{\text {rd }}$ edition.- Prentice Hall, pp. 718, New Jersey. 